\title{
The Moderation Effect of Innovativeness on the Relationship between Overall Quality and Actual Usage of Smart Government
}

\author{
Ali Ameen ${ }^{1 *}$, Dawood Al-Ali ${ }^{1}$, Fathey Mohammed ${ }^{2}$, Osama Isaac ${ }^{1}$, Ibrahim \\ Alrajawy $^{1}$, Dhoha Younis ${ }^{1}$ \\ ${ }^{1}$ Lincoln University College, Selangor, Malaysia \\ ${ }^{2}$ School of Computing, Universiti Utara Malaysia, 06010 Sintok, Kedah, Malaysia \\ *ali.ameen@aol.com
}

\begin{abstract}
This study utilizes structural equation modelling using SmartPLS 3.0 to process the data collected from 401 responses to assess the moderation effect of innovativeness on the relationship between the overall quality and actual usage of smart government in United Arab Emirates (UAE) from employees perspective. A model is proposed based on Delone \& Mclean information system success model with considering the literature and the context of the study. Overall quality is proposed to be a second-order construct which includes three different aspects of quality; system quality, information quality, and service quality. In addition, innovativeness is proposed as a moderating variable which may control the relationship between the overall quality and actual usage of smart government. Results indicated that overall quality significantly influences the actual usage of smart government. The overall quality explains $44.7 \%$ of the variance in actual usage. Furthermore, the impact of the overall quality on the actual use is moderated by the innovativeness. This work enhances the insight into the significance of innovativeness in using smart government services.
\end{abstract}

Keywords: Smart government, system quality, information quality, service quality, innovativeness. 


\section{Introduction}

Internet technology has transformed the way organizations operate by representing the backbone of the different managerial functions. As the world is witnessing a huge increase on the number of internet users and the advancement of mobile gadgets capabilities, in addition to delivering numerous benefits, information technology have dominated every aspect of our lives all over the globe. This phenomenon has led the majority of organizations have directed significant share of its resources towards new technologies as a powerful tool to achieve its operational and strategic goals to eventually gain a competitive advantage (Venkatesh, Morris, Davis, \& Davis, 2003).

The actual use of smart government can be affected by factors such as overall quality in terms of system, information, and service quality (A. Ameen \& Ahmad, 2011; A. Ameen, Rahmah, et al., 2020; Haddad et al., 2020; Sudhana, Ameen, \& Isaac, 2020; Almarri, Ameen, Bhaumik, Alrajawy, \& Khalifa, 2020; Haddad et al., 2020; Sulistyowati, Alrajawy, Yulianto, Isaac, \& Ameen, 2020). Among the manifestations of information technology is the smart government, which is considered as an effective tool to enhance the communication and service delivery of public organizations to organizations and individuals alike (Rahman, AlBalooshi, \& Sarker, 2015). Information technology is rapidly advancing and changing which makes it vital for employees and organizations to keep pace with such change by continuing the adaption and training of individual with the evolving technology (Kassim, Ramayah, \& Kurnia, 2012), as organizations around the world struggle to keep up to date with emerging technology.

One of the main sectors affected by the growth of IT is the public sector (Mohammed, Ibrahim, \& Technologies, 2015). In most contemporary government agencies, the use of technology is not only dependent on information and communication technologies to fill in some forms and records, but it is also a tool that performs the process of identifying, classifying, analyzing, measuring, preparing and interpreting, and communicating information (A. A. Ameen \& Ahmad, 2012; A. Ameen \& Ahmad, 2013, 2014, 2017; A. Ameen, Al-ali, Isaac, \& Mohammed, 2020; A. Ameen et al., 2019; A. B. Ameen \& Ahmad, 2013).

One of the key goals of public management or provision of government services is to improve public satisfaction with the government. In addition, the growing information needs by different stakeholders, increasing urban population to a greater extent, the lack of effective and efficient communication channels between the government and residents, a lack of best knowledge management practices are a few critical issues that the UAE government is aiming to resolve through smart government initiatives in the country. Moreover, it is clear that the ultimate outcome of smart government initiatives is to enhance the quality of lives in the country. This study aims at investigating the effect of the quality of systems, information, and services on actual usage of smart government services, in addition 
to the moderating role of innovativeness among employees in Abu Dhabi's public sector in the United Arab Emirates.

\section{The Proposed Conceptual Model}

This study proposed model is constructed to achieve the aim of the study by using DeLone \& McLean success model as lences to identify the relationships. In addition, the literature and the context of the study are considerd. Accordingly, three main constructs are included; overall quality, innovativeness and actual use.

1) Overall Quality (QUL): Overall quality encompasses systems, information, and service qualities. System quality refers to the reliability, suitability of the system, in addition to the stability of the hardware and software (DeLone \& Mclean, 2003). These concepts are reflected in terms of functionality, ease of use, understandability, reliability, and flexibility (Petter \& McLean, 2009). Besides, information quality denotes the characteristics of the output of the system in terms of being complete, accurate, and up-to-date (Petter \& McLean, 2009), in addition to accessibility, understanding, and relevance as described by Tam \& Oliveira (2016). Moreover, service quality is related to the realization of the service delivered with regard to fulfilling the requirements of users, in terms of satisfaction and expectations (Parasuraman et al., 1985). In the context of IS research, in their updated information system success model, Delone \& McLean (2003) have referred to service quality through these attributes: tangibles, reliability, responsiveness, assurance, and empathy. Many research have been published which investigated the role of system quality in many technology applications. In the knowledge management systems context, two studies in Taiwan and Malaysia by Wang \& Lai (2014) and Cham et al. (2016) respectively, have found that system quality has a significant positive relationship with usage, and user satisfaction. Moreover, according to Chiu et al. (2016) who conducted a study in Taiwan on cloud ebookcase system indicated that there is a significant positive relationship between service quality and actual usage. The above arguments and other supporting results led to the following hypothesis:

H1: Overall quality significantly influences actual usage of smart government.

2) Innovativeness (INN): Innovativeness as a concept can be understood as differences among individuals which can be depicted in the responses of people towards new things ( $\mathrm{Ng}, \mathrm{Kee}, \&$ Ramayah, 2019). It also refers to the pursuit of unusual, novel or creative solutions to the different needs and problems, whether it is the creation of new services, products, technologies, and processes for the purpose of executing the functions of an organization (such as, delivery, administration, production, promotion, packaging, sales) (Yen, Teng, \& Tzeng, 2020). The organization's innovativeness is related to the structures and policies that affect its ability to implement creative ideas and turn them into innovative products or services (Zhang, Sun, Liu, \& Chang, 2020). Consequently, the following 
hypothesis is proposed:

$\mathrm{H} 2$ : Innovativeness strengthen the positive effect of overall quality on actual usage of smart government.

3) Actual Usage Smart Government (USE): The actual usage of technology was described as the manner and degree to which users utilizes the capabilities of the information systems, the frequency and amount of usage, nature, appropriateness, extent and purpose of the usage (DeLone and McLean 2016). Kim et al. (2007) stated that actual usage parameter reflects the frequency of the usage of the technology along with the usage time. Thus, actual usage was defined as consumption of the IS along with the output which was based on the actual or the self-reported usage (Petter and McLean 2009). Kim et al. (2015) investigated Mobile Customer Relationship Management (M-CRM) in South Korea and concluded that the usage could significantly affect personal performance.

Fig. 1 illustrates the proposed model second order construct containing overall quality, innovativeness and actual usage. These relationships are adapted based on DeLone \& McLean (2003), and is studied among employees in Abu Dhabi's public sector in the United Arab Emirates. The proposed model has two hypotheses to be examined.

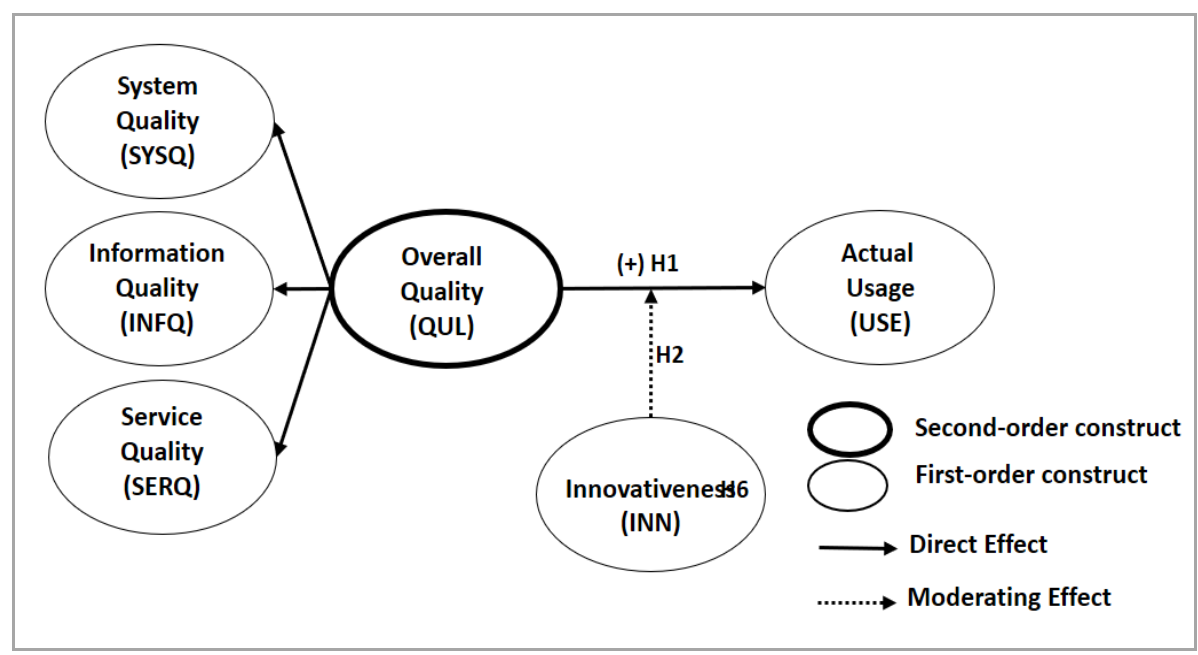

Fig. 1: The proposed conceptual model

\section{Research Methods}

In this study, the researchers developed the questionnaire tool which consists of 15 questions. All parameters were assessed using the 5 Likert scale based on similar studies in the literature (Isaac et al., 2017a; Isaac et al., 2017b; Almazroi, Shen, \& Mohammed, 2018). This instrument was used to collect by delivering the selfmanaged questionnaire 'in-person' to the employees in the Abu Dhabi's public 
sector agencies, UAE, in the period between December 2019 and February 2020. Out of 500 questionnaires that were distributed, 401 responses were seen to be suitable for analysis. This sample size was sufficient as stated by Krejcie and Morgan (1970) and Tabachnick and Fidell (2012). SEM-VB via SmartPLS 3.0 (Ringle, Wende, \& Becker, 2015) was used to analyse the data and to test the main hypotheses of this study as recommended by related studies (Isaac, Abdullah, Aldholay, \& Ameen, 2019; Isaac, Abdullah, Ramayah, \& Mutahar, 2017; Mutahar, Daud, Thurasamy, Isaac, \& Abdulsalam, 2018).

\section{Results and Discussion}

\subsection{Assessment of Measurement Model}

The composite reliability (CR), Cronbach's alpha, The average variance extracted (AVE), and the factor loadings are fulfill the requirements (Kline, 2010; Hair, Black, Babin, \& Anderson, 2010) as illustrated in Table 1.

Table 1: Measurement model assessment

\begin{tabular}{|c|c|c|c|c|c|c|c|}
\hline Constructs & Item & $\begin{array}{c}\text { Loading } \\
(>0.7)\end{array}$ & $\mathbf{M}$ & SD & $\begin{array}{c}\alpha \\
(>0.7)\end{array}$ & $\begin{array}{c}\text { CR } \\
(>\mathbf{0 . 7})\end{array}$ & $\begin{array}{c}\text { AVE } \\
(>0.5)\end{array}$ \\
\hline $\begin{array}{l}\text { System } \\
\text { Quality } \\
\text { (SYSQ) }\end{array}$ & $\begin{array}{l}\text { SYSQ1 } \\
\text { SYSQ2 } \\
\text { SYSQ3 }\end{array}$ & $\begin{array}{l}0.897 \\
0.922 \\
0.922\end{array}$ & 3.02 & 1.14 & 0.901 & 0.938 & 0.835 \\
\hline $\begin{array}{c}\text { Information } \\
\text { Quality } \\
\text { (INFQ) }\end{array}$ & $\begin{array}{l}\text { INFQ1 } \\
\text { INFQ2 } \\
\text { INFQ3 }\end{array}$ & $\begin{array}{l}0.927 \\
0.928 \\
0.909\end{array}$ & 3.12 & 1.17 & 0.911 & 0.944 & 0.849 \\
\hline $\begin{array}{l}\text { Service } \\
\text { Quality } \\
\text { (SERQ) }\end{array}$ & $\begin{array}{l}\text { SERQ1 } \\
\text { SERQ2 } \\
\text { SERQ3 } \\
\end{array}$ & $\begin{array}{l}0.943 \\
0.940 \\
0.958 \\
\end{array}$ & 3.19 & 1.24 & 0.942 & 0.963 & 0.897 \\
\hline $\begin{array}{l}\text { Actual Usage } \\
\text { (USE) }\end{array}$ & $\begin{array}{l}\text { USE1 } \\
\text { USE2 } \\
\text { USE3 } \\
\end{array}$ & $\begin{array}{l}0.917 \\
0.953 \\
0.931 \\
\end{array}$ & 3.04 & 1.11 & 0.927 & 0.953 & 0.872 \\
\hline $\begin{array}{c}\text { Innovativeness } \\
\text { (INN) }\end{array}$ & $\begin{array}{l}\text { INN1 } \\
\text { INN2 } \\
\text { INN3 }\end{array}$ & $\begin{array}{l}0.919 \\
0.935 \\
0.966\end{array}$ & 3.28 & 1.06 & 0.935 & 0.958 & 0.885 \\
\hline
\end{tabular}

Note: $\alpha=$ Cronbach's alpha; $\mathrm{CR}=$ Composite Reliability, $\mathrm{M}=\mathrm{Mean}$; $\mathrm{SD}=$ Standard Deviation, $\mathrm{AVE}=$ Average Variance Extracted.

Fornell-Larcker was used to test the discriminant validity, table 2 shows that all constructs of model fulfilled satisfactorily (Fornell \& Larcker, 1981; Chin, 1998; Hair et al., 2017).

Table 2: Fornell-Larcker criterion

\begin{tabular}{|c|c|c|c|c|c|}
\hline & USE & INFQ & INN & SERQ & SYSQ \\
\hline USE & $\mathbf{0 . 9 3 4}$ & & & & \\
\hline
\end{tabular}




\begin{tabular}{|c|c|c|c|c|c|}
\hline INFQ & 0.413 & $\mathbf{0 . 9 2 1}$ & & & \\
\hline INN & 0.623 & 0.373 & $\mathbf{0 . 9 4 1}$ & & \\
\hline SERQ & 0.429 & 0.725 & 0.381 & $\mathbf{0 . 9 4 7}$ & \\
\hline SYSQ & 0.421 & 0.639 & -0.437 & 0.622 & $\mathbf{0 . 9 1 4}$ \\
\hline
\end{tabular}

Note: Diagonals represent the square root of the average variance extracted while the other entries represent the correlations.

\subsection{Assessment of Structural Model}

According to Hair, Hult, Ringle, \& Sarstedt, (2017) the structural model can be tested by bootstrapping procedure with a resample of 5,000, see Fig. 2.

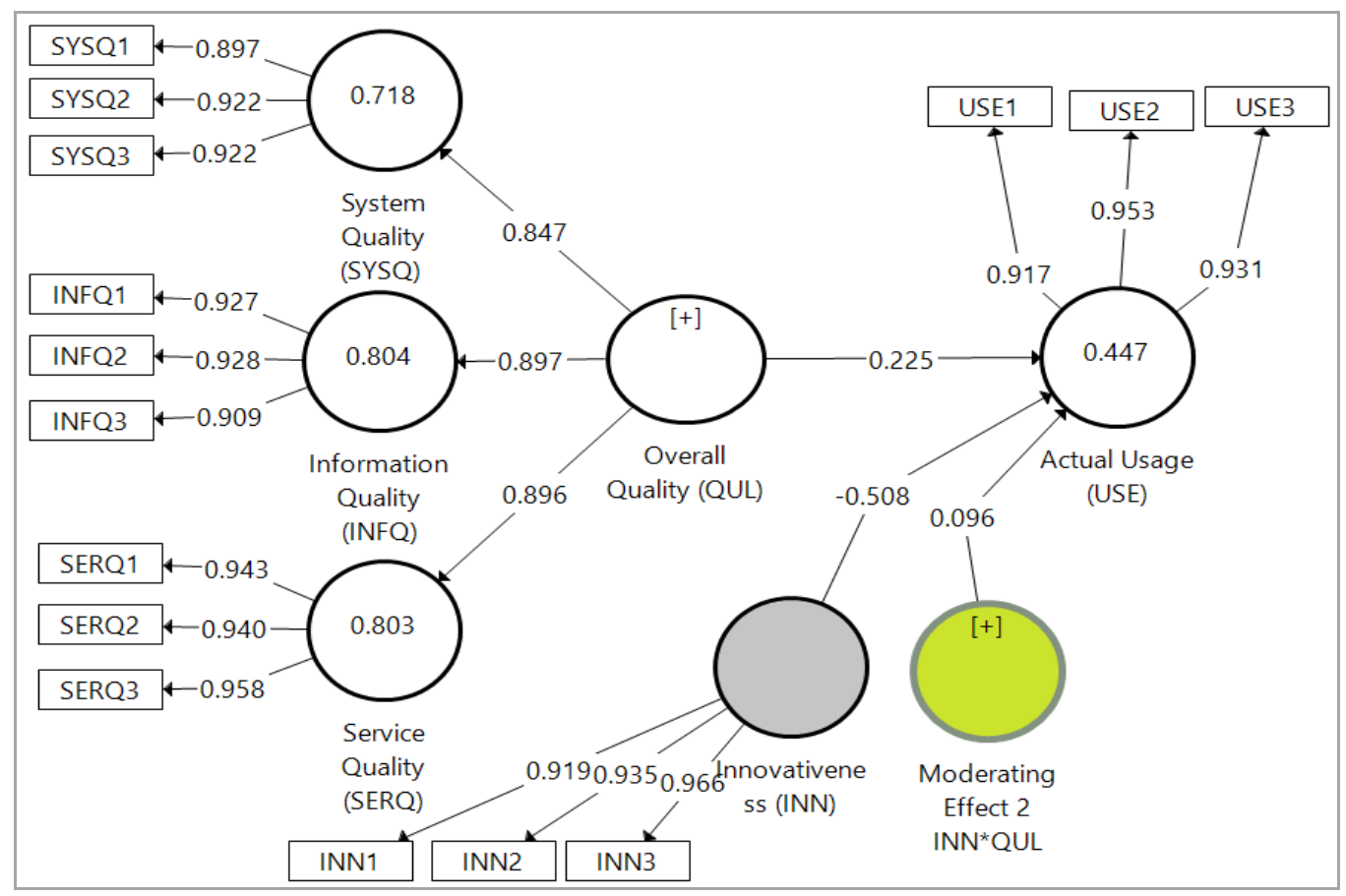

Fig. 2: PLS algorithm results

A. Direct Hypothesis Results: Fig. 2 and Table III depict the structural model assessment illustrating the hypothesis testing results. Overall quality positively influences actual usage smart government. Hence, H1 is accepted with $(\beta=0.225, \mathrm{t}=4.854, \mathrm{p}<0.001)$. According to Chin, (1998) and Cohen, (1988) the value of 0.45 of $\mathrm{R}^{2}$ indicating regarding the explanatory power as acceptable level. 
Table 3: Direct Hypothesis Results

\begin{tabular}{|c|c|c|c|c|c|c|c|}
\hline Hypothesis & Relationship & Beta & Std Error & t-value & p-value & Decision & $\mathbf{R}^{2}$ \\
\hline H1 & QUL $\rightarrow$ USE & 0.225 & 0.046 & 4.854 & 0.000 & Supported & 0.45 \\
\hline
\end{tabular}

Note: QUL: overall quality; USE: actual usage

B. Moderating Effect Hypotheses: By applying bootstrapping technique the interaction effect was assessed. The results (as shown in Fig. 3 and Table 4) showed that innovativeness moderates (strengthen) the positive impact of overall quality on actual usage smart government $(\beta=0.096, \mathrm{t}=2.644, \mathrm{p}<0.01)$, so, H2 is accepted.

Table 4: Moderating Hypothesis Results

\begin{tabular}{|c|c|c|c|c|c|c|}
\hline \multicolumn{2}{|c|}{ Hypothesis } & Beta & Std Error & t-value & p-value & Decision \\
\hline \multirow{3}{*}{ H2 } & H2.a: QUL $\rightarrow$ USE & 0.225 & 0.046 & 4.854 & 0.000 & \\
\cline { 2 - 6 } & H2.b: INN $\rightarrow$ USE & -0.508 & 0.045 & 11.378 & 0.000 & \multirow{2}{*}{ Supported } \\
\cline { 2 - 6 } & H2.c: QUL*INN $\rightarrow$ USE & 0.096 & 0.036 & 2.644 & 0.008 & \\
\hline
\end{tabular}

Key: QUL: overall quality, innovativeness (INN), USE: actual usage

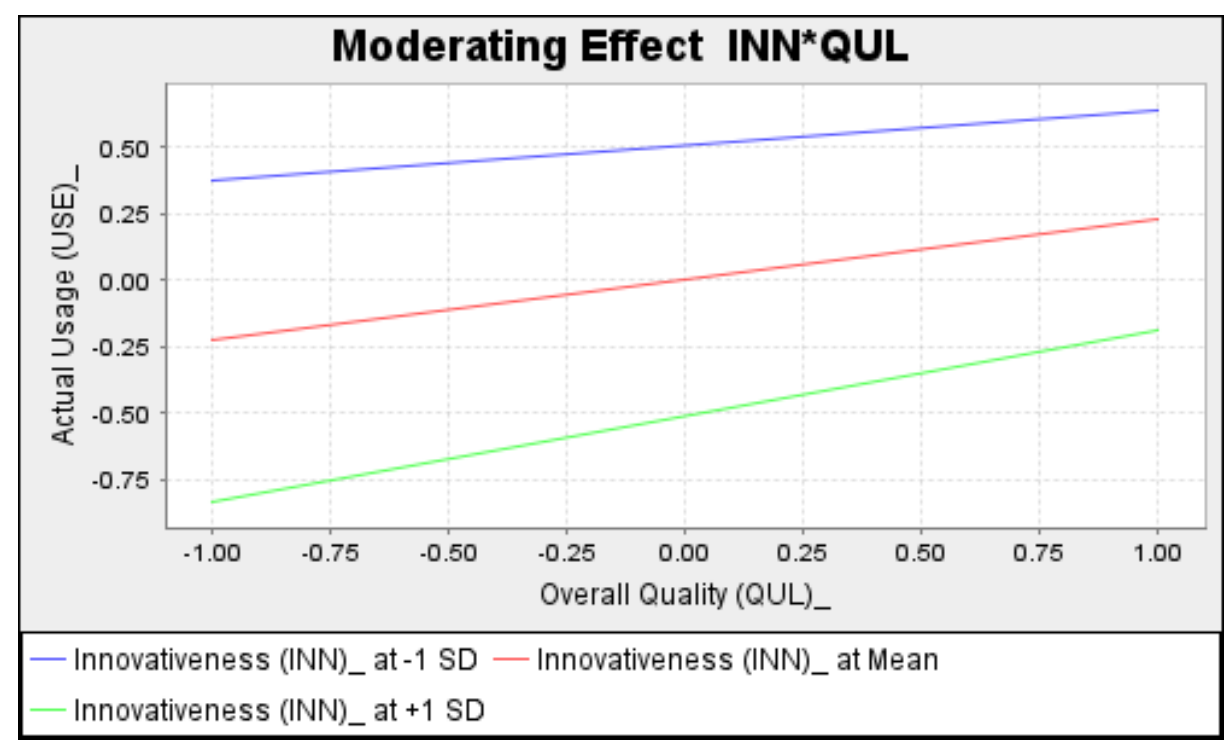

Fig. 3: Moderating effects result

\subsection{Discussion}

The hypothses testing results confirmed the positive effect of the overall quality on actual usage of smart government services from the prespective of employees in Abu Dhabi's public sector agencies in the UAE. This is alined with the results of previous studies (Aldholay, Isaac, Abdullah, \& Ramayah, 2018; Isaac, Abdullah, Ramayah, \& Mutahar, 2018; Abrego-Almazán et al., 2017; Chiu et al., 2016; Tam $\&$ Oliveira, 2016). This confirms the fact that the more the employees find smart 
government services are easy to use and flexible, with clear and understandable interaction mode, and provide up-to-date, relevant and accurate information, employees are able to use smart government at the time or place he/she wants, find platforms that are relevant to his/her tasks, and being able to communicate interactively through it. The more regular is employee's use of smart government services, prefer communication through smart government services, and promote the use of smart government services use to others.

Further, the results show that innovativeness has a significant moderating effect (strengthen) between overall quality and actual use among employees in Abu Dhabi's public sector in the United Arab Emirates, which confirms the moderation role that innovativeness has in this context. Simply stated, the more the employees find smart government is of high quality in terms of system, information and services, employees can use smart government at the time or place he/she wants, find platforms that are relevant to his/her tasks, and being able to communicate interactively through it, The more regular is employees' use of smart government services, prefer communication through smart government services, and promote the use of smart government services use to others. Given that employees like to do experiment with new information technology, keep looking for ways to try new technologies.

\section{Conclusions}

In this study, the important conclusions noted were with regards to the objectives. Objective 1 aimed to determine the role of overall quality in influencing actual use of smart government services in the governmental sectors of Abu Dhabi. Good results were noted in the study which highlighted a novel perspective. The researchers proposed a new model, wherein they considered overall quality as the independent variable, while innovativeness as a moderating variable which represents objective 2. According to the results, both hypotheses were significant. Furthermore, the independent variable could explain $44.7 \%$ of the variation noted in the actual usage.

This study can be considered very relevant for the Abu Dhabi government since the smart government initiatives was applied to improve the efficiency of public services for employees and people residing in the UAE alike. In this study, the researchers evaluated and measured employee actual usage of such services, which was the outcome of the successful establishment of the UAE Smart Government activities. Thus, the findings noted in the study highlighted how technological characteristics and employee's innovativeness have influenced their usage, which further helped the UAE government make appropriate decisions related to their activities. Top management at the government institutions have to realize and make use of smart government service and to create the necessary strategies to influence populations of users who are less likely to utilize such technology in their work, the 
reason for such strategies is to get their employees prepared with the adequate skills to accumulate experience of using smart government services. The benefits of such use will not only be limited to improving employee's professional practice, enhancing personal development and working life quality, but also contributing to public institutions in achieving their strategic goals.

\section{References}

Abrego-Almazán, D., Sánchez-Tovar, Y., and Medina-Quintero, J. M. (2017). Influence of information systems on organizational results. Contaduría $y$ Administración, 62(2), 321-338.

Aldholay, A. H., Isaac, O., Abdullah, Z., and Ramayah, T. (2018). The Role of Transformational Leadership as a Mediating Variable in DeLone and McLean Information System Success Model: The Context of Online Learning usage in Yemen. Telematics and Informatics, 35(5),1421-1437.

Almarri, H., Ameen, A., Bhaumik, A., Alrajawy, I., and Khalifa, G. S. A. (2020). The Mediating Effect of Facilitating Conditions on The Relationship Between Actual Usage of Online Social Networks (OSN) and User Satisfaction. International Journal of Psychosocial Rehabilitation, 24(06), 6389-6400.

Almazroi, A. A., Shen, H., and Mohammed, F. (2018, June). The impact of trust on the adoption of cloud computing services by university students. In International Conference of Reliable Information and Communication Technology, Springer, Cham, 902-911.

Ameen, A. A., and Ahmad, K. (2012). Towards Harnessing Financial Information Systems in Reducing Corruption: A Review of Strategies. Australian Journal of Basic and Applied Sciences, 6(8), 500-509.

Ameen, A., and Ahmad, K. (2011). The Role of Finance Information Systems in anti financial corruptions: A theoretical review. 11 International Conference on Research and Innovation in Information Systems, 6125725, 267-272.

Ameen, A., and Ahmad, K. (2013). Proposing Strategy for Utilizing Financial Information Systems in Reducing Corruption. 3rd International Conference on Research and Innovation in Information Systems - 2013 (ICRIIS'13), 1 , 75-80. 
Ameen, A., and Ahmad, K. (2014). A Systematic Strategy for Harnessing Financial Information Systems in Fighting Corruption Electronically. Knowledge Management International Conference (KMICe), Malaysia, 12-15. Retrieved from http://www.kmice.cms.net.my/

Ameen, A., and Ahmad, K. (2017). Information Systems Strategies to Reduce Financial Corruption. In S. M. Benlamri R. (Ed.), Springer Proceedings in Business and Economics, 1, 731-740.

Ameen, A., Al-ali, D., Isaac, O., and Mohammed, F. (2020). Examining relationship between service quality, user satisfaction, and performance impact in the context of smart government in UAE. International Journal of Electrical and Computer Engineering (IJECE), 10(6), 6026-6033.

Ameen, A., Almari, H., Isaac, O., Mohammed, F., Amin, A., Almari, H., and Mohammed, F. (2019). Investigating the Key Factors Influencing the Use of Online Social Networks in Public Sector Context in the UAE. International Journal of Innovation, 7(3), 392-411.

Ameen, A. B., and Ahmad, K. (2013). A Conceptual Framework of Financial Information Systems to reduce corruption. Journal of Theoretical and Applied Information Technology, 54(1), 59-72.

Ameen, A., Rahmah, M., Isaac, O., Balaganesh, D., Midhunchakkravarthy, and Midhunchakkravarthy, D. (2020). The Impact of Organizational Innovation on Financial Performance: A Perspective of Employees Within Dubai Ports World BT - Intelligent Computing and Innovation on Data Science. In S.-L. Peng, L. H. Son, G. Suseendran, and D. Balaganesh (Eds.), Intelligent Computing and Innovation on Data Science. Lecture Notes in Networks and Systems. Singapore: Springer Singapore, 475-483

Cham, T. H., Lim, Y. M., Cheng, B. L., and Lee, T. H. (2016). Determinants of knowledge management systems success in the banking industry. VINE Journal of Information and Knowledge Management Systems, 46(1), 2-20.

Cheng, D., Liu, G., Qian, C., and Song, Y.-F. (2013). Customer Acceptance of Internet Banking: Integrating Trust and Quality with UTAUT Model. IEEE, 1(1), 383-388.

Chin, W. W. (1998a). Issues and opinion on structural equation modeling. MIS Quarterly, 22(1), 7-16. 
Chin, W. W. (1998b). The partial least squares approach to structural equation modeling. In G. A. Marcoulides (Ed.), Modern methods for business research. New Jersey: Lawrence Erlbaum Associates. Mahwah, NJ: Lawrence Erlbaum, 295-358.

Chiu, P.-S., Chao, I.-C., Kao, C.-C., Pu, Y.-H., and Huang, Y.-M. (2016). Implementation and evaluation of mobile e-books in a cloud bookcase using the information system success model. Library Hi Tech, 34(2), 207-223.

Cohen, J. (1988). Statistical power analysis for the behavioral sciences (2nd ed.). Hillsdale, Lawrence Erlbaum Associates.

DeLone, W H, and Mclean, E. R. (2003). The DeLone and McLean Model of Information Systems Success: A Ten-Year Update. Journal of Management Information Systems / Spring, 19(4), 9-30.

DeLone, William H., and McLean, E. R. (2016). Information Systems Success Measurement. In Series in Information Technology Management. now Publishers Inc. PO.

DeLone, William H, and McLean, E. (2003). The DeLone and McLean model of information systems success: A ten-year updated. Journal of Management Information Systems, 19(4), 9-30.

Fornell, C., and Larcker, D. F. (1981). Evaluating structural equation models with unobservable variables and measurement error. Journal of Marketing Research, 18(1), 39-50.

Haddad, A., Ameen, A., Isaac, O., Alrajawy, I., Al-shbami, A., and Midhun Chakkaravarthy, D. (2020). The Impact of Technology Readiness on the Big Data Adoption Among UAE Organisations. In N. Sharma, A. Chakrabarti, \& V. E. Balas (Eds.), Data Management, Analytics and Innovation,1016, 249-264.

Hair, J. F., Black, W. C., Babin, B. J., and Anderson, R. E. (2010). Multivariate Data Analysis. New Jersey.

Hair, J. F. J., Hult, G. T. M., Ringle, C., and Sarstedt, M.(2014). A Primer on Partial Least Squares Structural Equation Modeling (PLS-SEM). 46 Long Range Planning $\S(2014)$.

Isaac, O., Abdullah, Z., Aldholay, A. H., and Abdulbaqi Ameen, A. (2019). Antecedents and outcomes of internet usage within organisations in Yemen: An 
extension of the Unified Theory of Acceptance and Use of Technology (UTAUT) model. Asia Pacific Management Review, 24(4), 335-354.

Isaac, O., Abdullah, Z., Ramayah, T., and Mutahar, A. M. (2017). Internet usage , user satisfaction, task-technology fit , and performance impact among public sector employees in Yemen. The International Journal of Information and Learning Technology, 34(3), 210-241.

Isaac, O., Abdullah, Z., Ramayah, T., and Mutahar, A. M. (2018). Factors determining user satisfaction of internet usage among public sector employees in Yemen. International Journal of Technological Learning, Innovation and Development, 10(1).

Isaac, O., Abdullah, Z., Ramayah, T., Mutahar, A. M., and Alrajawy, I. (2017). Towards a Better Understanding of Internet Technology Usage by Yemeni Employees in the Public Sector: An Extension of the Task-Technology Fit (TTF) Model. Research Journal of Applied Sciences, 12(2), 205-223.

Kassim, N. M., Ramayah, T., and Kurnia, S. (2012). Antecedents and outcomes of human resource information system (HRIS) use. International Journal of Productivity and Performance Management, 61(6), 603-623.

Kim, C., Lee, I.-S., Wang, T., and Mirusmonov, M. (2015). Evaluating effects of mobile CRM on employees' performance. Industrial Management and Data Systems, 115(4), 740-764.

Kim, H.-W., Chan, H. C., and Gupta, S. (2007). Value-based Adoption of Mobile Internet: An empirical investigation. Decision Support Systems, 43(1), 111-126.

Kline, R. B. (2010). Principles and practice of structural equation modeling (3rd ed.). New York: The Guilford Press.

Krejcie, R. V, and Morgan, D. W. (1970). Determining sample size for research activities. Educational and Psychological Measurement, 38, 607-610.

Lin, F., Fofanah, S. S., and Liang, D. (2011). Assessing citizen adoption of eGovernment initiatives in Gambia: A validation of the technology acceptance model in information systems success. Government Information Quarterly, 28(2), 271-279.

Lin, H. F. (2007). Predicting consumer intentions to shop online: An empirical test of competing theories. Electronic Commerce Research and Applications, 6, 433442 . 
Lin, W.-S., and Wang, C.-H. (2012). Antecedences to continued intentions of adopting e-learning system in blended learning instruction: A contingency framework based on models of information system success and task-technology fit. Computers and Education, 58(1), 88-99.

Mohammed, F., Ibrahim, O. B. J. I. J. o. D. S., and Technologies. (2015). Drivers of cloud computing adoption for E-government services implementation. 6(1), 1-14.

Mohammadi, H. (2015). Investigating users perspectives on e-learning: An integration of TAM and IS success model. Computers in Human Behavior, 45(1), 359-374.

Mutahar, A. M., Daud, N. M., Thurasamy, R., Isaac, O., and Abdulsalam, R. (2018). The Mediating of Perceived Usefulness and Perceived Ease of Use: The Case of Mobile Banking in Yemen. International Journal of Technology Diffusion, 9(2).

Ng, H. S., Kee, D. M. H., and Ramayah, T. (2019). Examining the mediating role of innovativeness in the link between core competencies and SME performance. Journal of Small Business and Enterprise Development, 27(1), 103-129.

Ngai, E. W. T., Poon, J. K. L., and Chan, Y. H. C. (2007). Empirical examination of the adoption of WebCT using TAM. Computers \& Education, 48(1), 250-267.

Nistor, N., Lerche, T., Weinberger, A., Ceobanu, C., and Heymann, O. (2014). Towards the integration of culture into the Unified Theory of Acceptance and Use of Technology. British Journal of Educational Technology, 45(1), 36-55.

Parasuraman, A., Zeithaml, V. A., and Berry, L. L. (1985). Model Service Its Quality and Implications for Future. The Journal of Marketing, 49(4), 41-50.

Pituch, K. A., and Lee, Y. (2006). The influence of system characteristics on elearning use. Computers and Education, 47(1), 222-244.

Rahman, M. H., AlBalooshi, S. A. and Sarker, A. E. (2015). The UAE Model of Smart Government: An Exploratory Analysis. National University of Public Service, 15-16.

Ringle, C. M., Wende, S., and Becker, J.-M. (2015). SmartPLS 3. Bonningstedt: SmartPLS. 
Sudhana, P., Ameen, A., and Isaac, O. (2020). A multi-theoretical framework to better understand the college major choice in arts and design. Journal of Applied Research in Higher Education, ahead-of-p(ahead-of-print).

Sulistyowati, W. A., Alrajawy, I., Yulianto, A., Isaac, O., and Ameen, A. (2020). Factors Contributing to E-Government Adoption in Indonesia - An Extended of Technology Acceptance Model with Trust : A Conceptual Framework. In Intelligent Computing and Innovation on, 651-658.

Tabachnick, B. G., and Fidell, L. S. (2007). Using Multivariate Statistics. PsycCRITIQUES, 28, 980.

Tam, C., and Oliveira, T. (2016). Understanding the impact of m-banking on individual performance: DeLone \& McLean and TTF perspective. Computers in Human Behavior, 61(1), 233-244.

Venkatesh, V., Morris, M. G., Davis, G. B., and Davis, F. D. (2003). USER ACCEPTANCE OF INFORMATION TECHNOLOGY: TOWARD A UNIFIED VIEW. 27(3), 425-478.

Wang, W.-T., and Lai, Y.-J. (2014). Examining the adoption of KMS in organizations from an integrated perspective of technology, individual, and organization. Computers in Human Behavior, 38(1), 55-67.

Yen, C. H., Teng, H. Y., and Tzeng, J. C. (2020). Innovativeness and customer value co-creation behaviors: Mediating role of customer engagement. International Journal of Hospitality Management, 88(March), 102514.

Zhang, F., Sun, S., Liu, C., and Chang, V. (2020). Consumer innovativeness, product innovation and smart toys. Electronic Commerce Research and Applications, 41(February), 100974.

Zhou, T. (2011). An empirical examination of initial trust in mobile banking. Internet Research, 21(5), 527-540. 